\title{
PERAN BRAND IMAGE MEMEDIASI PENGARUH KUALITAS PRODUK TERHADAP NIAT BELI ULANG (Studi pada Smartphone Samsung di Kota Denpasar)
}

\author{
I Ketut Catur Hery Suartama ${ }^{1}$ \\ Putu Yudi Setiawan ${ }^{2}$ \\ ${ }^{1,2}$ Fakultas Ekonomi dan Bisnis Universitas Udayana, Bali, Indonesia \\ Email: suartamahery@gmail.com
}

\begin{abstract}
ABSTRAK
Tujuan dari penelitian ini adalah untuk mengetahui peran brand image dalam memediasi pengaruh kualitas produk terhadap niat beli ulang. Penelitian ini dilakukan di Kota Denpasar. Jumlah sampel sebanyak 105 responden, dengan metodenon probability sampling. Teknik pengambilan sampel ditentukan dengan teknikpurposive sampling berdasarkan pertimbangan tertentu yaitu, tingkat pendidikan minimal SMA/sederajat, sudah pernah membeli produk smartphone Samsung, mengetahui informasi mengenai produk smartphone Samsung, dan berdomisili di Kota Denpasar. Data primer diperoleh dengan menyebar kuisioner dan dianalisis memakai SEM (Structural equation modeling) yang memiliki basiscomponent ataupunvariance yaitu PLS (Partial Least Square). Hasil analisis data menunjukkan bahwa kualitas produk berpengaruh positif dan signifikan terhadap brand image, kualitas produk dan brand image berpengaruh positif dan signifikan terhadap niat beli ulang, brand image mampu memediasi pengaruh kualitas produk terhadap niat beli ulang.
\end{abstract}

Kata kunci : kualitas produk, brand image, niat beli ulang

\begin{abstract}
The purpose of this study was to determine the role of brand image in mediating the effect of product quality on repurchase intention. The number of samples is 105 respondents.. The sampling method was determined by a purposive sampling method based on certain considerations, namely, the education level of at least high school / equivalent, had bought Samsung smartphone products, found out information about Samsung smartphone products, and lived in the city of Denpasar. Primary data was obtained by distributing questionnaires and analyzed using SEM (Structural equation modeling) data analysis based on component or variance, namely PLS (Partial Least Square). The results of data analysis show that product quality has a positive and significant effect on brand image, product quality and brand image have a positive and significant effect on repurchase intention, brand image is able to mediate the effect of product quality on repurchase intention.
\end{abstract}

Keyword : product quality, brand image, repurchase intention 


\section{PENDAHULUAN}

Perkembangan dunia modern dan globalisasi saat ini suatu kebutuhan akan komunikasi adalah hal yang sangat penting bagi setiap kalangan masyarakat.Rasa butuh untuk alat komunikasi contohnya telepon seluler (handphone) ataupunsmartphone sendiri sering mendapatkan penambahan sepanjang tahunkhususnya untuk jenis-jenis handphone ataupunsmartphone dengan merkmerk tertentu.Hal tersebut disebabkan oleh pola konsumtif pembeli di era global ini yang selalu ingin sebuah kemudahan didalam komunikasi yang bisamemberi dukungan kegiatan mereka sehari-hari baik didalam pekerjaan ataupun hal yang lain-lain.Pilihan pembeliagarmemakai handphone ataupunsmartphone saat ini sangatlahbesar seperti salah satunya kenaikan penjualan untukhandphone ataupunsmartphone Samsung. Pernyataan tersebutdibuktikanmelalui lembaga riset Gartner penjualansmartphone sepanjang kuartal kedua 2017 memperoleh peningkatan 7,6 persen di sepanjang tahun.

Sampai detik ini produk Samsung masihlahjadi sebuahorganisasi yang memasarkan produknya di Indonesia, menunjukan sangat besarnya minat konsumsi Samsung di Indonesia. Menurut Madahi et al.(2012) minat konsumen merupakan rasa ingin yang muncul melalui proses pengaktifan memori sebagai suatu rencana yang disimpan. Niat beli konsumen merupakan tahapan pelanggandidalam membuat pilihan mereka antara sekian banyak merk yang bergabung didalam perangkat pilihan, lalupada akhirnya melaksanakan sebuahproses membeliuntuk sebuah alternatif yang sangat disukai ataupun proses 
yang akankonsumen lewati dalam tahapanpembelian sebuah produk yang berdasar kepada macam-macam pertimbangan (Annafik dan Rahardjo, 2012).

Tabel 1.

5 vendor Smartphone Terbesar di Indonesia Tahun 2016 dan 2017

2017 Top Smartphone

Companies

\begin{tabular}{|c|c|c|c|}
\hline \multicolumn{2}{|c|}{ Companies } & \multicolumn{2}{|c|}{ Companies } \\
\hline Company & Market Share & Company & Market Share \\
\hline 1. Samsung & $31.8 \%$ & 1. Samsung & $28.8 \%$ \\
\hline 2. OPPO & $22.9 \%$ & 2. OPPO & $16.6 \%$ \\
\hline 3. Advan & $7.7 \%$ & 3. ASUS & $10.5 \%$ \\
\hline 4. ASUS & $6.5 \%$ & 4. Advan & $6.8 \%$ \\
\hline 5. Vivo & $6.0 \%$ & 5. Lenovo & $5.6 \%$ \\
\hline Others & $25.1 \%$ & Others & $31.6 \%$ \\
\hline Total Shipment & & Total Shipment & \\
\hline $\begin{array}{l}\text { Volumes } \\
\text { (in millions) }\end{array}$ & 30.04.00 & $\begin{array}{l}\text { Volumes } \\
\text { (in millions) }\end{array}$ & 30.03 .00 \\
\hline
\end{tabular}

2016 Top Smartphone

Companies

Tabel diatas menunjukan penjulan Samsung mengalami kenaikan dari tahun 2016 ke tahun 2017, begitu pula dengan Oppo dan Advan yang penjualannya mengalami peningkatan, namun tidak untuk Asus yang mengalami penurunan penjualan, dan ditahun 2017 tercatan merek baru yang berhasil menduduki pringkat 5 besar smartphone yang menguasai pasar Indonesia, yaitu Vivo yang menggantikan posisi Lenovo ditahun sebelumnya. Secara keseluruhan penjulan smartphone di Indonesia mengalami peningktan yaitu dari 30.3 juta unit menjadi 30.4 unit. Saat ini Samsung menjadi market leader penjulan smartphone di Indonesia dengan pangsa pasar $31,8 \%$, pada peringkat kedua dibawah Samsung yaitu Oppo dengan pangsa pasar 22,9\%, pada peringkat ketiga yaitu Advan dengan pangsa pasar 7,7\%, pada peringkat keempat yaitu Asus dengan pangsa pasar 6,5\%, dan pada peringkat kelima yaitu Vivo dengan pangsa pasar 6,0\%, dan sisanya diisi oleh merek lain sebesar $25,1 \%$. 
Samsung menarik untuk diteliti karena Samsung merupakan market leadersmartphone di Indonesia yang mampu bertahan cukup lama dari sekian tahun hingga saat ini, dan mampu merebut posisi teratas dari Blackberry dan Nokia yang merupakan market leader handphone di Indonesia ditahun-tahun sebelumnya, dan untuk mengetahui faktor-faktor apa yang mempengaruhi penjualan Samsung di Indonesia yang berkaitan dengan variabel penelitian. Dengan hal ituperusahaan Samsung tentu haruslah memakai strategi yang sesuai, serta selalu melakukan pengembangan ide-ide baruuntuk produk tapi selalu ingatuntuk memberi perhatian terhadap kualitas produk. Menurut (Kotler dan Armstrong, 2012: 283) kualitas produk adalah kemampuan sebuah produk dalam memperagakan fungsinya, hal ini termasuk keseluruhan durabilitas, reliabelitas, ketepatan, kemudahan pengoperasian, reparasi produk, dan atribut produk lainnya. Produk harus memiliki tingkat kualitas tertentu karena produk dibuat untuk memenuhi selera konsumen atau memuaskan pemakainya.

Sebelum pembeli memakai sebuah barang atau jasa yang akan dibelinya, pembeli cendrung menggunakan infoyang didapat dari orang lain yang sudah lebih dulu memakaibarang atau jasaitu. Mengkonsumsi atau menggunakan sebuahbarang atau jasadikarenakanbrand image produk tersebut adalah suatu pertimbangan yang dilakukan pembelididalm memakaibarang atau jasa yang nanti bisa memberi manfaat yang diutuhkan.Brand image menurut (Roslina, 2010) adalah petunjuk yang bisa dipakai oleh pembeli dalamproses pengevaluasianbarang atau jasasaatpembeli tidaklah mempunyai ilmu yang mencukupimengenaisebuah barang atau jasa. Hal ini dikarenakan brand image 
yang bagusdapat memberi kemudahanpelanggandidalam mengenal sebuahbarang atau jasajugamembentukpandangan yang bagus akan kualitas barang dan jasa serta membuat munculnya niat beli bahkan niat beli ulang konsumen padabarang atau jasa itu. Menurut Andreani et al.(2012) Pembelian ulang dipengaruhi oleh faktor citra merek yang positif, karena dengan citra merek yang kuat dapat menyebabkan konsumen menjadi loyal. Menurut (Suciningtyas, 2012) Citra merek yang positif mempunyai pengaruh yang positif pada keputusan pembelian, semakin tinggi brand image yang diciptakan oleh perusahaan maka tingkat pengambilan keputusan untuk membeli juga semakin meningkat. Menurut (Musaddad, 2011) hal ini dapat dilakukan dengan menanamkan persepsi subyektif kepada konsumen saat pengkonsumsian barang atau jasa hingga konsumen berminat untuk melakukan pembelian ulang.

Penelitian berikut dilaksanakanberdasar kepada sekian hasil dari penelitian sebelumnya mengenai pengaruh brand image, kualitas produk serta niat beli ulang dengan hasil yang beragam. Hasil penelitian dari (Afif, 2017) memberi pernyataan bahwasannya kualitas produk tidaklahmemiliki pengaruh signifikan pada niat beli ulang. Hal tersebut sejalan dengan hasil penelitian (Arfiani, 2015) menyatakan bahwasannya kualitas produk tidaklahmempunyai pengaruh signifikan pada niat beli ulang. Hasil penelitian tersebuttidak sejalan dengan penelitian(Pebriana, 2016) yang memberi pernyataan bahwasannya kualitas produk sertabrand image mempunyaipengaruh positif pada niat beli ulang. Hasiltersebutsama dengan dengan hasil penelitian (Astiani, 2014) kualitas produk mempunyai pengaruh signifikan pada niat beli ulang.Penelitian berikut dilaksanakan untuk 
I Ketut Catur Hery Suartama, Peran Brand Image...

pengembangan studi dari penelitian-penelitian yang sudah dilaksanakan sebelumnya. Berdasarkan research GAP tersebut dan dari latar belakang masalah yang sudah dijelaskan maka perlu dilakukan penelitian mengenai "Peran Brand Image Dalam Memediasi Pengaruh Kualitas Produk Terhadap Niat Beli Ulang” pada produk smartphone merek Samsung di Kota Denpasar.

Berdasar kepada latar belakang masalah yang diteliti, penelitian berikut tergolong sebuah penelitian assosiatif (hubungan), adalah penelitian yang memiliki tujuan ahar diketahuinya hubungan dari dua variable ataupun lebih (Sugiyono, 2017: 5). Peneliti ini menguji hipotesis yang menjelaskan pengaruh kualitas produk padabrand image, pengaruh kualitas produk terhadap niat beli ulang, pengaruh brand image terhadap niat beli ulang serta peranbrand image memediasi kualitas produk dan niat beli ulang. Kerangka penelitian ini dapat dilihat pada Gambar 1:

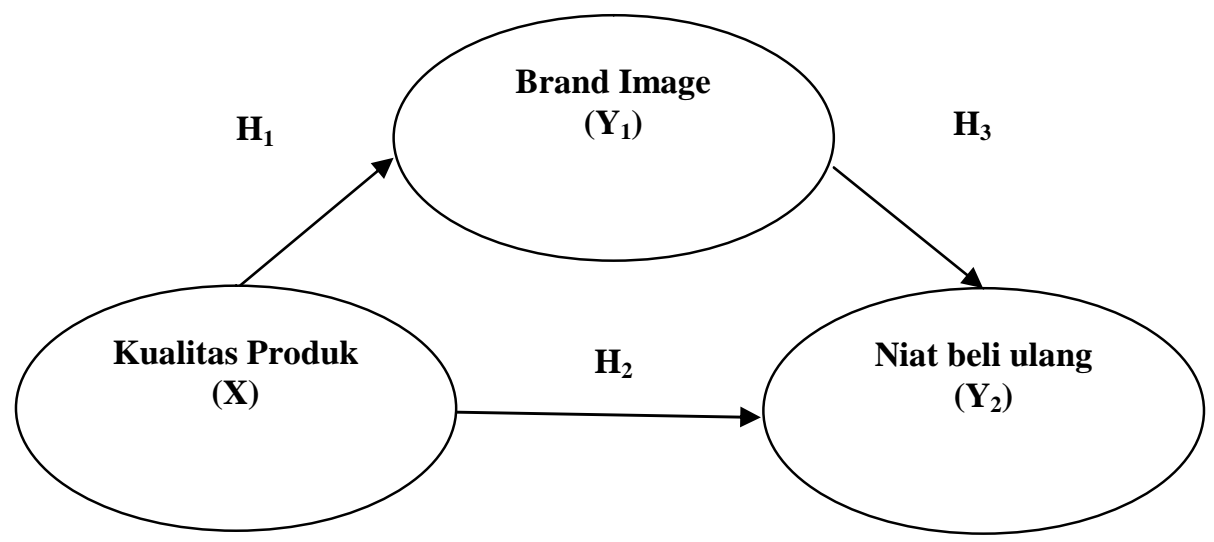

\section{Gambar 1. Kerangka Konseptual}

Sumber: Data Diolah, 2018

Jakpar et al. (2012) menyatakan sekian elemen yang bisa memberi ukuran terhadapkualitas produk, adalah : daya tahan (durability) yang mana kenyamanan (comfortmance), kehandalah (reliability), sertamudah atau tidaknya perawatannya (serviceability). Pelanggandapatmemberikan penilaian sebuahbarang atau 
jasamemiliki kualitas tinggi bila mempunyai elemen-elemen berikut serta tentu ini bisamenampilkan mampu atau tidaknya melakukan pemenuhan kebutuhan pelanggan serta cocok dengan harapan mereka padabarang atau jasa. Kualitas sebuahbarang atau jasa bisamemberi pengaruh konsumen didalam proses terbentuknya citra suatu merk. Bila kualitas barang atau jasa suatu merk yang terjual tinggi jadipelangganbisa mengasosiakan kualitas produk yang tinggi di merk itu, yang mempunyai arti citra merek ituadalah bagus.

Penelitian yang dilaksanakan oleh (Meganita \& Sitinjak, 2014) mendapatkan bahwasannya citra merek yang bagusbisadiciptakan dari meningkatkan kualitas barang atau jasa. Kualitas prodok jadi suatu hal yang sangatlah vitaldikarenakan hal tersebut terkait dengan kepercayaan pelangganpadabarang ataupun jasaseraorganisasi itu sendiri dikarenakan kualitas yang bagus dapat menimbulkan citra yang positif dalam benakpelanggan jadinyapelanggan jadi lebih percaya padabarang atau jasa itu(Anis,2015). Hasil tentang hubungan kualitas barang atau jasaserta citra merk punditeliti oleh(Nuraini, 2015) yang memberikan penjelasan bahwasannya kualitas produk yang besarmemberikan cerminan citra merk yang bagus, khususnya untuk merk yang menjual produk brupa barang, pelanggan pasti menilai bagusatau jeleknya citra merk daripadaatribut-atribut barang ataupun jasaituterutama kualitasnya.Berdasar kepada telaah sertakajian penelitian terdahulu jadibisatersaji hipotesa seperti berikut :

$\mathrm{H}_{1}$ : Kualitas produk berpengaruh positif dan signifikan terhadap brand image 
Menurut Kotler dan Amstrong(2014:374) kualitas produk yaitumampu atau tidaknya sebuahbarang atau jasadalam melaksanakan fungsi-fungsinya, kemampuan ini termasuk daya tahan, keandalan, ketelitian yang dihasilkan, kemudahan dioperasikan serta diperbaiki, juga atribut lainnya yang mempunyai nilaidibarang atau jasa secara keseluruhan. Menurut American Society for Quality Controldidalam Lupiyoadi(2001) kualitas yaitu seluruh ciri-ciri serta karakteristik-karakteristik dari sebuahproduk, didalam hal ini mampu atau tidaknyamelakukan pemenuhan kebutuhan-kebutuhan yang sudah ditetapkan.

Penelitian sebelumnya yang mempunyai judul "Analisis Pengaruh Kualitas Pelayanan, Kualitas Produk dan Promosi Penjualan terhadap Minat Beli Ulang (Studi pada Konsumen Buket Koffee dan Jazz)” oleh Triastuti R.J (2012) memberikan petunjuk ada atau tidaknya pengaruh positif variable kualitas barang atau jasa pada niat beli ulang. Penelitian lainnyapula dilaksanakan Saidani dan Arifin (2012) yang memberikan petunjuk bahwasannya kualitas barang atau jasa memiliki pengaruh positif serta signifikan pada niat beli ulang. Dengan hasil penelitian bahwasannya kualitas barang ataupun jasa mempunyai pengaruh yang paling tinggi, kualitas barang atau jasamakin terjaga sertasemakin meningkatjadidapat menciptakan niat beli ulang yang besar.Berdasarkan telaah dan kajian penelitian terdahulu, maka dapat disusun hipotesis sebagai berikut :

$\mathrm{H}_{2}$ : Kualitas produk berpengaruh positif dan signifikan terhadap niat beli ulang.

Rangkuti (2002 : 2) menyatakan merk adalah janji penjualagardengan konsisten memberi fitur, manfaat serta jasa khususpada konsumen. Tariq et al. (2013) memberikan pernyataan bahwasannya citra merk merupakan aspek yang 
vital padaproses membeli. Ini memberikan bantuanpembeli agarmelakukan keputusan merk mana yang akan terpilih yang merupakan pilihan yang lebih bagus lagiuntuk merekaserta konsumenterpaksaagar membentuk niat untuk membelihinggasekian kali. Sebuah citra yang bagus menolongagarterciptannya hubungan jangka panjang diantara barang dan jasaserta pemakaiterakhir. Berdasarkan penelitian yang dilaksanakan(Wijaya, 2014) juga menunjukkan bahwa kelakuanbaikpelanggan pada sebuah merk bisamemberi peningkatan niat beli pelangganataupunbarang dan jasaitu, hal berikut tejadi saat pelanggan merasakankepuasanpadaproduk yang diterima dari sebuahorganisasiyang menyediakanprodukitu, jadi sangatlahtinggi kemungkinannya untuk pelanggan melaksanakanproses membelikembali.Berdasarkan telaah dan kajian penelitian terdahulu, maka dapat disusun hipotesis sebagai berikut:

$\mathrm{H}_{3}$ : Brand image berpengaruh positif dan signifikan terhadap niat beli ulang.

Berdasar kepada penelitian yang dilaksanakan oleh (Anggitan, 2013) menunjukkan bahwasannya kualitas barang atau jasa mempunyai pengaruh positif langsung dengan niat beli ulang baik denganlangsung atau lewatbrand image. Vazquez-Carrasco and Foxall didalam (Thakur dan Singh, 2012) yang memberikan pernyataan bahwa diantara variable yang dipakaidalampengukuran ada atau tidaknya pengaruh pada niat beli ulang untuk sebuahbarang atau jasa yang jadi objek di penelitiannya adalah salah satunya memakai variablebrand image, penelitian itu memberikan bukti adanya hubungan positif diantara brand image dengan niat beli ulang. 
Saraswati (2014) menyatakan bahwa brand image yang memiliki pengaruh nyata pada pembelian ulang yaitu produk yang mempunyai variasi, fungsi yang cocok dengan keinginan, serta harga yang bisa dijangkau. Hal serupa dengan hasil uji penelitian yang dilaksanakan oleh Andriadi dan Untarini (2013) bahwasannyacitra merk disebuah dimensinya mempunyai pengaruh yang signifikan yang bisa memberikan bentuk niat beli ulang konsumen.Pebriana (2016) didalam hasil penelitiannya mendapatkan bahwasannya kualitas barang atau jasa lewatbrand image memiliki pengaruh secara positif serta signifikan pada niat beli ulang.Berdasarkan telaah dan kajian penelitian terdahulu, maka dapat disusun hipotesis sebagai berikut :

$\mathrm{H}_{4}$ : Brand image berperan dalam memediasi pengaruh kualitas produk terhadap niat beli ulang.

\section{METODE PENELITIAN}

Penelitian ini menguji hipotesis yang menjelaskan pengaruh kualitas barang atau jasa padabrand image, pengaruh kualitas barang atau jasa pada niat beli ulang, pengaruh brand image pada niat beli ulang serta peran brand image menjadi mediasi kualitas barang atau jasajuga niat beli ulang.Penelitian berikut dilaksanakan di Kota Denpasar. Lokasi ini terpilihdikarenakan Kota Denpasar adalah pusat perekonomian di Bali, selain itu agar mempermudah pengumpulan data karena banyak terdapat sekolah-sekolah dan kampus.Subjek dalam penelitian ini adalah konsumen yang sudah pernah membeli dan menggunakan smartphoneSamsung. Obyek pada penelitian berikutyaitu pengaruh kualitas produk $(\mathrm{X})$ terhadap brand image $\left(\mathrm{Y}_{1}\right)$, pengaruh kualitas produk $(\mathrm{X})$ terhadap 
niat beli ulang $\left(\mathrm{Y}_{2}\right)$, pengaruh brand image $\left(\mathrm{Y}_{1}\right)$ terhadap niat beli ulang $\left(\mathrm{Y}_{2}\right)$, peran brand image $\left(\mathrm{Y}_{1}\right)$ memediasi kualitas produk $(\mathrm{X})$ dan niat beli ulang $\left(\mathrm{Y}_{2}\right)$.

Kualitas produk adalah kondisi dari sebuah produk yang mencerminkan karakteristik dari handphone atau smartphoneSamsung untuk menjalankan tugasnya berdasarkan pada standar ukur yang telah ditetapkan oleh perusahaan.Brand image adalah anggapan sebuah merek yang dipikirkan oleh konsumen dan tertanam dibenak konsumen yang selalu diingat oleh konsumen smartphone Samsung. Niat beli ulang merupakan keinginan atau tindakan konsumen untuk mebeli ulang produk smartphoneSamsung, karena adanya kepuasan yang diterima sesuai yang diinginkan. Selengkapnya definisi operasional variabel akan disampaikan didalam tabel berikut:

Tabel 2.

Definisi Operasional Variabel

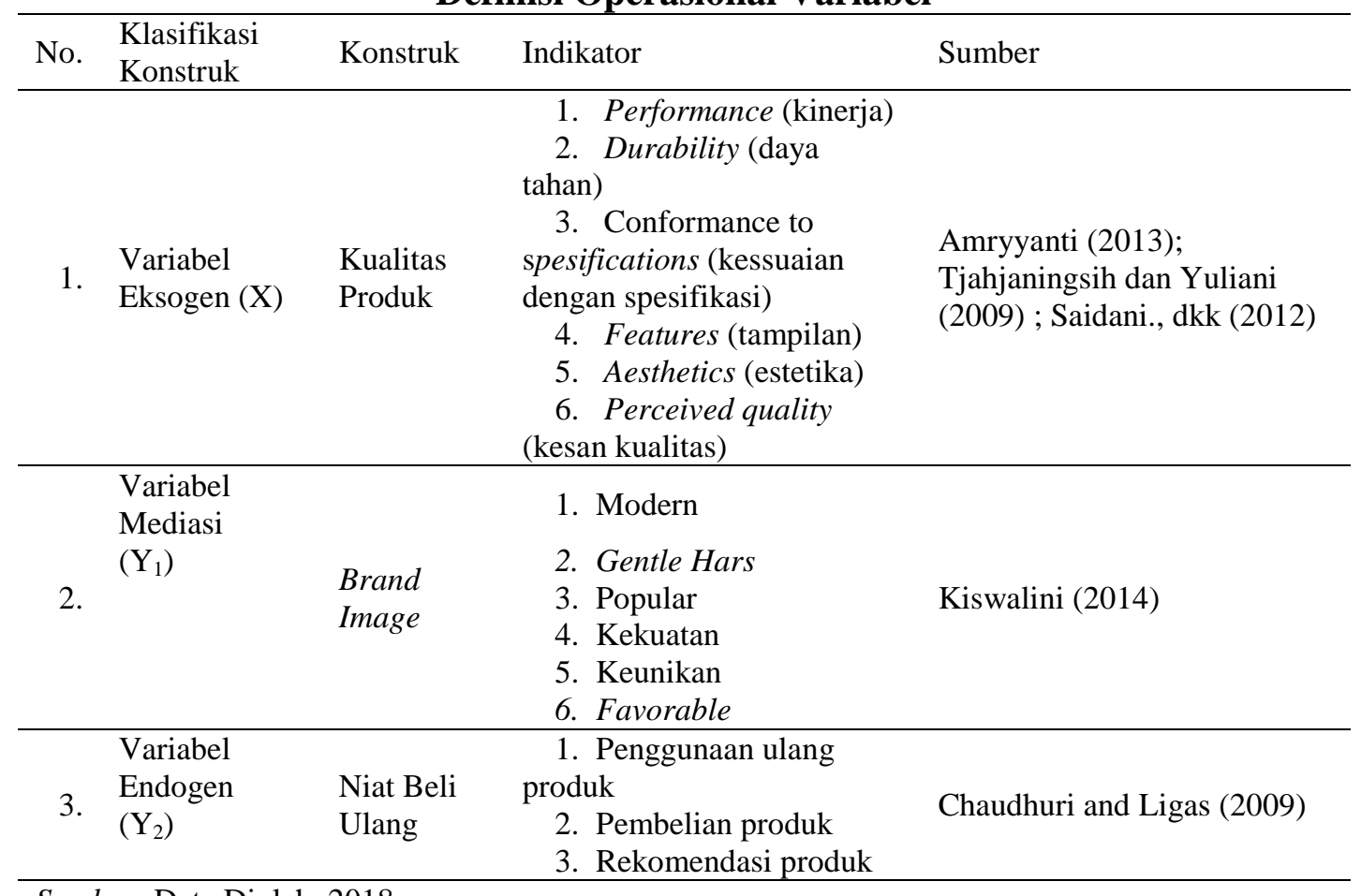

Sumber: Data Diolah, 2018 
Populasi didalam penelitian berikutyaitupelanggan yang pernah melakukan pembeliansertamenggunakan smartphoneSamsung. Populasi bersifat infinite karena jumlahnya tidaklah diketahui dengan pasti.Secara umum sampel berarti sebagai bagian daripada sebuah populasi. Sampel merupakan jumlah sebagian daripada karakter yang dipunyai oleh populasi itu. (Sugiyono,2017:81) menyatakan metode penentuan sampel yang dipakaididalam penelitian berikut yaitunon probability sampling. Teknik pengambilan sampel ditentukan dengan metode purposive sampling adalah metode memilih sampel berdasar kepadapersyaratanyang telah ditentukan (Sugiyono, 2017:85). Adapun kriteria responden yang diambil sebagai sampel adalah sebagai berikut: 1) Tingkat pendidikan minimal SMA/sederajat, diasumsikan bahwasannya responden dengan tingkat pendidikan minimum SMA bisapaham serta memjawab kuisioner dengan lebih baik. 2) Sudah pernah membeli produk SmartphoneSamsung. Kriteria ini dipakai karena penelitian ini membahas mengenai niat beli ulang dari konsumen. 3) Mengetahui informasi mengenai produk smartphoneSamsung.4) Berdomisili di Kota Denpasar. Kriteria ini dipakai karena penelitian ini dilakukan di Kota Denpasar, sehingga nantinya data akan menjadi lebih valid apabila responden berdomisisli di Kota Denpasar.

Jumlah responden dalam penelitian ini ditentukan sebesar 5-10 kali total indikatornya(Sugiyono,2017:130). Total sampel responden yang akan diuji didapatkan dari hasil yang dihitung seperti berikut: Jumlah responden $=15 \times 7=$ 105 responden.Metode pengumpulan data dalam penelitian ini adalah dengan menggunakan kuisioner.Tipe pertanyaan di kuisioner yaitu pertanyaan tertutup, 
responden diminta untuk memilih dari sekian alternatif pilihan jawaban yang adapada kuisioner. Alternatif yang adadidalam kuisioner adalah berkembang dari tiap-tiap item didalam variable penelitian.Data kuantitatif yang dikumpulkan dalam penelitian ini adalah data hasil dari tanggapan responden terhadap kuisioner yang diberikan sesuai dengan sampel yang telah ditentukan.Data kualitatif yang langsung dikumpulkan dari konsumen yang berada di Kota Denpasar, guna mendapatkan gambaran apakah konsumen tersebut berniat atau tidak membeli ulang produk smartphoneSamsung. Data primer dalam penelitian ini dikumpulkan melalui hasil wawancara dan jawaban dari kuisioner yang disebarkan pada responden atau konsumen yang berniat membeli ulang produk smartphone Samsung.Data sekunder dalam penelitian ini yaitu data yang dikumpulkan dari berita-berita online maupun studi empiris mengenai kualitas produk, brand image, dan niat beli ulang.

Penelitian berikut memakai teknik analisis data yang disebut analisis SEM (structural equation modeling) yang memiliki basis component ataupunvariance yaitu PLS (partial least square). Menurut (Ghozali, 2011:18), PLS adalahfactor inderteminancy metode analisa yang kuat dikarenakantidaklah memberikan asumsi data harus menggunakan pengukuran skala khusus, jumlah sampel kecil, bisa dipakaidalam melakukan konfirmasi teori, serta menolongagar mendapat nilai variable laten sebagai tujuan prediksi.Model evaluasi PLS berdasarkan pada pengukuran prediksi yang mempunyai sifat non - parametrik. Evaluasi model terdiri atas dua bagian evaluasi yaitu evaluasi model struktural (inner model) dan evaluasi model pengukuran (outer model).Pengujian hipotesis dilakukan dengan 
uji statistik t ( $t$-test). Apabila dalam pengujian ini diperoleh $\mathrm{p}$-value $<0,05$ (alpha 5 persen) berarti pengujian signifikan, dan sebaliknya apabila $\mathrm{p}$-value $>0,05$ (alpha 5 persen), berarti tidak signifikan.

\section{HASIL DAN PEMBAHASAN}

Karakteristik responden pada penelitian peran brand image sebagai mediasi pengaruh kualitas produk pada niat beli ulang (studi pada smartphone samsung di Kota Denpasar), dapat dilihat dari beberapa kriteria yaitu : Jenis Kelamin, Umur, Pendidikan terakhir yang diselesaikan, Pekerjaan, berikut disajikan karakteristik responden dari berbagai kriteria tersebut.

Tabel 3.

Karakteristik Responden

\begin{tabular}{|c|c|c|c|c|}
\hline No. & Variabel & Klasifikasi & Jumlah (orang) & Presentase $(\%)$ \\
\hline \multirow[t]{3}{*}{1} & \multirow{2}{*}{ Jenis Kelamin } & Laki-Laki & 56 & 53,33 \\
\hline & & Perempuan & 49 & 46,67 \\
\hline & Jumlah & & 105 & 100 \\
\hline \multirow{7}{*}{2} & \multirow{6}{*}{ Usia } & 17-21 Tahun & 33 & 26,67 \\
\hline & & 22-26 Tahun & 25 & 25,72 \\
\hline & & 27-31 Tahun & 21 & 21,9 \\
\hline & & 32-36 Tahun & 12 & 12,38 \\
\hline & & 37-42 Tahun & 8 & 7,62 \\
\hline & & $>42$ Tahun & 6 & 5,71 \\
\hline & Jumlah & & 105 & 100 \\
\hline \multirow{6}{*}{3} & \multirow{5}{*}{ Pekerjaan dan Status } & Pelajar/Mahasiswa & 42 & 40 \\
\hline & & Karyawan Swasta & 31 & 29,52 \\
\hline & & PNS & 19 & 18,1 \\
\hline & & Pengusaha & 9 & 8,57 \\
\hline & & Lain-Lain & 4 & 3,81 \\
\hline & Jumlah & & 105 & 100 \\
\hline \multirow{4}{*}{4} & \multirow{3}{*}{ Pendidikan Terakhir } & SMA/Sederajat & 19 & 18,1 \\
\hline & & Diploma & 34 & 32,38 \\
\hline & & $\mathrm{S} 1$ & 52 & 49,52 \\
\hline & Jumlah & & 105 & 100 \\
\hline
\end{tabular}


Proses uji instrumen penelitian dari pengujian validitas didapatkan hasil bahwasannya semua instrumen penelitian mempunyai nilai yang telah melakukan pemenuhan syarat apabila nilai signifikansi (p) $\mathrm{r}$ hitung lebih rendah daripadau $(0,05)$ serta nilai korelasi melebihi 0,3 (Sinkovics, 2009). Semua item dari variable kualitas produk $(\mathrm{X})$, variabel brand image $\left(\mathrm{Y}_{1}\right)$, dan variabel niat beli ulang $\left(\mathrm{Y}_{2}\right)$ memberikan petunjuk peluang $(\mathrm{p})$ yang lebih rendah daripadau $(0,05)$ dengan nilai $\mathrm{r}$ hitung yang melebihi $\mathrm{r}$ tabel $(0,361)$. Hasil pengujian validitas di Tabel 4 dibawahmemberikan petunjuk bahwasannya semua variable mempunyai nilai koefisien korelasi dengan nilai total semua item pertanyaan melebihi 0,30 . Hasil tersebut memberikan arti bahwasannya pernyataan-pernyataan didalam instrumen penelitian itu valid.

Tabel 4.

\section{Hasil Uji Validitas}

\begin{tabular}{cccc}
\hline Variabel & Indikator & Koefisien Korelasi & Keterangan \\
\hline & $\mathrm{X}_{.1}$ & .864 & Valid \\
Kualitas Produk & $\mathrm{X}_{.2}$ & .885 & Valid \\
$(\mathrm{X})$ & $\mathrm{X}_{.3}$ & .961 & Valid \\
& $\mathrm{X}_{.4}$ & .877 & Valid \\
& $\mathrm{X}_{.5}$ & .883 & Valid \\
& $\mathrm{X}_{.6}$ & .961 & Valid \\
\hline & $\mathrm{Y}_{1.1}$ & .867 & Valid \\
Brand Image & $\mathrm{Y}_{1.2}$ & .915 & Valid \\
$\left(\mathrm{Y}_{1}\right)$ & $\mathrm{Y}_{1.3}$ & .918 & Valid \\
& $\mathrm{Y}_{1.4}$ & .901 & Valid \\
& $\mathrm{Y}_{1.5}$ & .904 & Valid \\
& $\mathrm{Y}_{1.6}$ & .915 & Valid \\
\hline \multirow{3}{*}{ Niat Beli Ulang } & $\mathrm{Y}_{2.1}$ & .782 & Valid \\
$\left(\mathrm{Y}_{2}\right)$ & $\mathrm{Y}_{2.2}$ & .960 & Valid \\
\hline Sumber & $\mathrm{Y}_{2.3}$ & .928 & Valid \\
\hline
\end{tabular}

Sumber: Data Diolah, 2018

Proses uji instrumen penelitian dari sisi reliabilitas didapatkan hasil bahwasannya semua instrument penelitian yang digunakan yaitu reliabel dengan 
syarat nilai Alpha Cronbach melebihi 0,6 (Sugiyono, 2017).Adapun hasil dari uji reliabilitas dapat ditunjukan pada Tabel 5.

Tabel 5.

Hasil Uji Reliabilitas

\begin{tabular}{lccc}
\hline Variabel & Jumlah/Item & Cronbach alpha & Keterangan \\
\hline Kualitas Produk $\left(\mathrm{X}_{1}\right)$ & 6 & 0,954 & Reliabel \\
Brand Image $\left(\mathrm{Y}_{1}\right)$ & 6 & 0,952 & Reliabel \\
Niat Beli Ulang $\left(\mathrm{Y}_{2}\right)$ & 3 & 0,865 & Reliabel \\
\hline Sumber: Data Diolah, 2018 & & &
\end{tabular}

Berdasar kepada Tabel 5 seluruh variabel sudah memiliki nilai Alpha Cronbach lebih besar dari 0,6 yang berarti hasil yang stabil diperoleh apabila dilakukan pengukuran kembali.Penilaian responden tentang kualitas produk yang diukur dengan 6 item pernyataan yang disajikan pada Tabel 6 sebagai berikut.

\section{Tabel 6}

Jawaban Responden Tentang Kualitas Produk

\begin{tabular}{|c|c|c|c|c|c|c|c|c|}
\hline \multirow[t]{2}{*}{ No } & \multirow[t]{2}{*}{ Pernyataan } & \multicolumn{5}{|c|}{$\begin{array}{l}\text { Proporsi Jawaban } \\
\text { Responden }\end{array}$} & \multirow[t]{2}{*}{$\begin{array}{l}\text { Rata- } \\
\text { Rata }\end{array}$} & \multirow[t]{2}{*}{ Kriteria } \\
\hline & & STS & $\mathrm{TS}$ & $\mathrm{N}$ & $\mathrm{S}$ & SS & & \\
\hline 1 & $\begin{array}{l}\text { Menurut saya produk Smartphone } \\
\text { Samsung dapat membantu dalam } \\
\text { komunikasi dengan baik. }\end{array}$ & 0 & 15 & 21 & 54 & 15 & 3,66 & Baik \\
\hline 2 & $\begin{array}{l}\text { Menurut saya produk Smartphone } \\
\text { Samsung memiliki daya tahan bagus } \\
\text { dalam jangka panjang. }\end{array}$ & 3 & 9 & 18 & 62 & 13 & 3,7 & Baik \\
\hline 3 & $\begin{array}{l}\text { Menurut saya produk Smartphone } \\
\text { Samsung memiliki spesifikasi tinggi. }\end{array}$ & 6 & 16 & 9 & 63 & 11 & 3,54 & Baik \\
\hline 4 & $\begin{array}{l}\text { Menurut saya produk Smartphone } \\
\text { Samsung memiliki kamera yang bagus. }\end{array}$ & 3 & 9 & 18 & 54 & 21 & 3,77 & Baik \\
\hline 5 & $\begin{array}{l}\text { Menurut saya produk Smartphone } \\
\text { Samsung memiliki tampilan dan model } \\
\text { dengan perpaduan warna yang menarik }\end{array}$ & 6 & 16 & 8 & 60 & 15 & 3,59 & Baik \\
\hline 6 & $\begin{array}{l}\text { Menurut saya secara keseluruhan } \\
\text { produk Smartphone Samsung memiliki } \\
\text { kualitas yang baik. }\end{array}$ & 6 & 16 & 10 & 64 & 9 & 3,51 & Baik \\
\hline \multicolumn{2}{|c|}{ Rata-rata } & & & & & & 3,63 & Baik \\
\hline
\end{tabular}

Sumber: Data Diolah, 2018

Berdasar kepada Tabel 6 dapat kita ketahui pandangan responden tentang variable kualitas barang atau jasa yang mempunyai rata-rata paling tinggi sertapaling rendah yaitu seperti berikut:Variable kualitas produk yang 
mempunyairata-rata paling rendah yaitu pernyataan "Menurut saya secara keseluruhan produk Smartphone Samsung memiliki kualitas yang baik" didapatkan nilai rata-rata sejumlah 3,51 yang termasuk dalam kriteria baiktapi mempunyaibesaran rata-rata yang kecilbila berbanding dengan pernyataan yang lain, hal tersebut memiliki arti umum responden memberi anggapansecara keseluruhan produk Smartphone Samsung memiliki kualitas yang baik.Variabel kualitas produk yang mempunyai rata-rata paling tinggi yaitu pernyataan "Menurut saya produk Smartphone Samsung memiliki kamera yang bagus" didapatkanbesaran rata-rata sejumlah 3,77 yang termasukkedalam kriteria baik, hal tersebutmemiliki arti umum responden memberi anggapanproduk Smartphone Samsung mempunyai kamera yang bagus.

Tabel 7.

Jawaban Responden Tentang Brand Image

\begin{tabular}{|c|c|c|c|c|c|c|c|c|}
\hline \multirow[t]{2}{*}{ No } & \multirow[t]{2}{*}{ Pernyataan } & \multicolumn{5}{|c|}{$\begin{array}{l}\text { Proporsi Jawaban } \\
\text { Responden }\end{array}$} & \multirow[t]{2}{*}{$\begin{array}{l}\text { Rata- } \\
\text { Rata }\end{array}$} & \multirow[t]{2}{*}{ Kriteria } \\
\hline & & STS & TS & $\mathrm{N}$ & $\mathrm{S}$ & SS & & \\
\hline 1 & $\begin{array}{l}\text { Menurut saya produk } \\
\text { Smartphone } \\
\text { teknomsung memiliki } \\
\text { Sagi canggih. }\end{array}$ & 6 & 14 & 26 & 40 & 19 & 3,5 & Baik \\
\hline 2 & $\begin{array}{l}\text { Menurut saya produk } \\
\text { Smartphone } \\
\text { digunakan. }\end{array}$ & 3 & 15 & 20 & 53 & 14 & 3,57 & Baik \\
\hline 3 & $\begin{array}{l}\text { Menurut saya produk } \\
\text { Smartphone } \\
\text { banyak dikenal orang. }\end{array}$ & 3 & 13 & 17 & 63 & 9 & 3,59 & Baik \\
\hline 4 & $\begin{array}{lr}\begin{array}{l}\text { Menurut saya } \\
\text { Smartphone }\end{array} & \text { produk } \\
\text { menggunakan } & \text { material } \\
\text { berkualitas tinggi. } & \end{array}$ & 6 & 12 & 27 & 40 & 20 & 3,53 & Baik \\
\hline 5 & $\begin{array}{l}\text { Menurut sayaterdapat banyak } \\
\text { model produk Smartphone } \\
\text { Samsung. }\end{array}$ & 3 & 13 & 15 & 59 & 15 & 3,67 & Baik \\
\hline 6 & 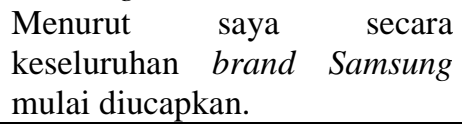 & 3 & 15 & 21 & 52 & 14 & 3,56 & Baik \\
\hline Rat & 1-rata & & & & & & 3,57 & Baik \\
\hline
\end{tabular}


Berdasar kepada tabel 7 bisa kita ketahui pandangan responden tentang variableBrand Image yang mempunyai rata-rata paling tinggi sertapaling rendah yaitu seperti berikut:VariableBrand Image yang mempunyai rata-rata paling rendah yaitu pernyataan "Menurut saya produk Smartphone Samsung memiliki teknologi canggih" didapatkan besaran rata-rata sejumlah 3,50 yang termasuk kedalam kriteria baik tapi mempunyaibesaran rata-rata yang rendah bila kita bandingkan dengan pernyataan yang lain, hal berikutmemiliki arti umum responden menganggap produk Smartphone Samsung memiliki teknologi canggih.Variabel Brand Image yang mempunyai rata-rata paling tinggi yaitu pernyataan "Menurut sayaterdapat banyak model produk Smartphone Samsung" didapatkanbesaran rata-rata sejumlah 3,67 yang termasuk kedalam kriteria baik, hal berikut memiliki arti umum responden memberikan anggapanterdapat banyak model produk Smartphone Samsung.

Tabel 8.

Jawaban Responden Tentang Niat Beli Ulang

\begin{tabular}{|c|c|c|c|c|c|c|c|c|}
\hline \multirow[t]{2}{*}{ No } & \multirow[t]{2}{*}{ Pernyataan } & \multicolumn{5}{|c|}{$\begin{array}{l}\text { Proporsi Jawaban } \\
\text { Responden }\end{array}$} & \multirow[t]{2}{*}{$\begin{array}{l}\text { Rata- } \\
\text { Rata }\end{array}$} & \multirow[t]{2}{*}{ Kriteria } \\
\hline & & STS & TS & $\mathrm{N}$ & $\mathrm{S}$ & SS & & \\
\hline 1 & $\begin{array}{l}\text { Saya akan membeli kembali produk } \\
\text { Smartphone Samsung. } \\
\text { Saya akan memilih produk Smartphone }\end{array}$ & 0 & 16 & 8 & 57 & 24 & 3,85 & Baik \\
\hline 2 & $\begin{array}{l}\text { Samsung pada kesempatan berikutnya } \\
\text { jika melakukan pembelian. } \\
\text { Saya akan merekomendasikan produk }\end{array}$ & 0 & 11 & 7 & 60 & 27 & 3,98 & Baik \\
\hline 3 & $\begin{array}{l}\text { Smartphone Samsung kepada rekan dan } \\
\text { teman. }\end{array}$ & 7 & 10 & 2 & 50 & 36 & 3,93 & Baik \\
\hline \multicolumn{2}{|c|}{ Rata-rata } & & & & & & 3,92 & Baik \\
\hline
\end{tabular}

Sumber: Data Diolah, 2018

Tabel 8 dapat kita ketahui pandangan responden tentang variable niat beli ulang yang mempunyai rata-rata paling tinggi serta paling rendah yaitu seperti berikut:Variable niat beli ulang yang mempunyai rata-rata paling rendah 
yaitupernyataan "Saya akan membeli kembali produk Smartphone Samsung" didapatkan nilai rata-rata sejumlah 3,85 yang termasuk dalam kriteria baik tapi mempunyai nilai rata-rata yang rendah bila berbanding dengan pernyataan yang lain, hal berikut memiliki arti umum responden memberikan anggapan akan membeli kembali produk Smartphone Samsung.Variabel niat beli ulang yang memiliki rata-rata tertinggi adalah pernyataan "Saya akan memilih produk Smartphone Samsung pada kesempatan berikutnya jika melakukan pembelian” didapatkanbesaran rata-rata sejumlah 3,98 yang termasuk dalam kriteria baik, hal berikutmemiliki arti umum responden memberikan anggapanakan memilih barang atau jasaSmartphone Samsung pada kesempatan berikutnya jika melakukan pembelian.

Menganalisis model penelitian dalam penelitian ini menggunakan metode PLS (partial least square) dengan alat bantu program smart PLS 3.2.7 terdapat dua evaluasi model mendasar dalam pengujian ini yaitu outer model dan inner model.Convergent validity dengan indikasi refleksif bisaterlihat dari korelasi diantara nilai indikasi dengan nilai variablenya. Indikasi individualmendapat anggapan reliable bila mempunyaibesaran korelasi diatas 0,70 . Tetapidi penelitian tahap perkembangan skala, loading 0,50 sampai dengan 0,60 masih bisa didapatkan Ghozali(2011:40). Hasil korelasi diantara indikator dengan variablenya bisaterlihat di Tabel 9 seperti berikut: 
Tabel 9.

Outer Loading

\begin{tabular}{|c|c|c|c|}
\hline & Original Sample (O) & $\begin{array}{c}\text { T Statistics } \\
\text { (1O/STDEVl) }\end{array}$ & P Values \\
\hline$X_{.1<- \text { Kualitas Produk }}$ & 0,864 & 33,591 & 0,000 \\
\hline $\mathbf{X}_{.2<- \text { Kualitas Produk }}$ & 0,853 & 19,555 & 0,000 \\
\hline $\mathbf{X}_{.3<\text { Kualitas Produk }}$ & 0,903 & 23,753 & 0,000 \\
\hline$X_{.4<-}$ Kualitas Produk & 0,886 & 41,303 & 0,000 \\
\hline $\mathbf{X}_{.5<- \text { Kualitas Produk }}$ & 0,904 & 36,763 & 0,000 \\
\hline$X_{.6<- \text { Kualitas Produk }}$ & 0,905 & 23,574 & 0,000 \\
\hline $\mathrm{Y}_{1.1<- \text { Brand Image }}$ & 0,866 & 30,920 & 0,000 \\
\hline $\mathbf{Y}_{1.2<\text { Brand Image }}$ & 0,937 & 69,520 & 0,000 \\
\hline$Y_{1.3<- \text { Brand Image }}$ & 0,937 & 66,177 & 0,000 \\
\hline $\mathbf{Y}_{1.4<- \text { Brand Image }}$ & 0,873 & 32,330 & 0,000 \\
\hline $\mathbf{Y}_{1.5<- \text { Brand Image }}$ & 0,913 & 50,725 & 0,000 \\
\hline $\mathbf{Y}_{1.6<\text { Brand Image }}$ & 0,934 & 66,123 & 0,000 \\
\hline $\mathbf{Y}_{2.1<-}$ Niat Beli Ulang & 0,895 & 23,603 & 0,000 \\
\hline $\mathbf{Y}_{2.2<-}$ Niat Beli Ulang & 0,943 & 91,669 & 0,000 \\
\hline $\mathbf{Y}_{2.3<-}$ Niat Beli Ulang & 0,945 & 93,095 & 0,000 \\
\hline
\end{tabular}

Sumber: Data diolah 2018.

Berdasar kepada Tabel 9, hasil keluaransudahlolos syaratconvergent validity dikarenakanfactor loading ada diatas 0,50. Dari variable kualitas barang atau jasa (X) indikator X.6 mempunyai nilai outer loading paling tinggi bila berbandingindicator-indikator lainnyasebesar 0,905 , jadi bisa diberikan penjelasan bahwasannya indikator itubisa memberikan refleksi variable kualitas produk (X). Dari variablebrand image $\left(\mathrm{Y}_{1}\right)$ indikator $\mathrm{Y} 1.2$ mempunyai besaranouter loading paling tinggi bila berbanding indikator lainnyaadalah 0,937, jadibisa diberikan penjelasan bahwasannya indikator itubisa memberikan refleksi variablebrand image $\left(\mathrm{Y}_{1}\right)$. Dari variable niat beli ulang $\left(\mathrm{Y}_{2}\right)$ indikator $\mathrm{Y} 2.3$ mempunyai besaranouter loading paling tinggi bila berbanding dengan indikator 
lainnyadimana nilainya 0,945 , jadibisa diberikan penjelasan bahwasannya indikator itubisa memberikan refleksivariable niat beli ulang (Y2).

Metode lainnyadalampenilaiandiscriminant validity yaitu membuat perbandingan akar kuadrat daripadaevarage variance extracted $(\sqrt{A})$ bagi tiap-tiap variable dengan korelasi diantara variable dengan variable lain didalam model. Model memilikidiscriminant validity yang mencukupi apabila akar kuadrat daripada AVE bagi tiap-tiap variablemelebihi dari korelasi diantara variable laindidalam model seperti yang ditampilkanpada Tabel 10.

Tabel 10.

Perbandingan akar kuadrat avarage variance extracted dan latent variable correlations

\begin{tabular}{ccc}
\hline Variabel Penelitian & AVE & Akar AVE \\
\hline Kualitas Produk (X) & 0,829 & 0,910 \\
Brand Image (Y1) & 0,785 & 0,886 \\
Niat Beli Ulang (Y2) & 0,861 & 0,928 \\
\hline
\end{tabular}

Sumber: Data diolah 2018.

Berdasar kepadaTabel 10, jadibisa diberikan penjelasan bahwasannya akar AVE di variable kualitas barang atau jasa sejumlah 0,910, brand image sejumlah 0,886 serta niat beli ulang sejumlah 0,928 , hasil berikut memberikan petunjuk bahwasannya nilai AVE masing-masing variablemelebihi 0,50 , hingga model berikutbisadikategorikan bagus.

Model struktural (inner model) bertujuan untuk memprediksi hubungan antar variabel laten. Dalam PLS prediksi hubungan ini dapat dilihat dari nilai $R$ square $\left(\mathrm{R}^{2}\right)$ untuk setiap variabel laten endogen sebagai kekuatan prediksi dari model structural. Penilaian model structural juga dapat dilakukan dengan $\mathrm{Q}^{2}$ predictive relevance yang juga disebut predictive sample reuse. 
Tabel 11.

R-square

R-square

Brand Image

0,790

Niat Beli Ulang

0,782

Sumber: Data diolah 2018.

Selanjutnya akan dihitung koefisien determinasi total adalah sebagai berikut:

$$
\begin{aligned}
\mathrm{Q}^{2} \quad & =1-\left(1-\mathrm{R}_{1}^{2}\right)\left(1-\mathrm{R}_{2}^{2}\right) \ldots \ldots . . \\
& =1-(1-0,790)(1-0,782) \\
& =1-(0,210)(0,218) \\
& =1-0,045 \\
& =0,955
\end{aligned}
$$

Besaran $\mathrm{Q}^{2}$ memiliki nilai dengan rentang $0<0,955<1$, dimana semakin mendekati 1 berarti model baik. pada perhitungan nilai koefisien determinasi total didapatkan sebesar 0,955 maka kesimpulannya adalah bahwa 95,5\% variabel brand image dan kualitas produk memiliki pengaruh terhadap niat beli ulang pada produk smartphone Samsung di kota Denpasar, sisanya sebesar 4,5\% dipengaruhi oleh variabel lain yang tidak dimasukkan dalam penelitian.Hasil analisis PLS masing-masing variabel bebas terhadap variabel terikatnya dapat dilihat pada Tabel 12 sebagai berikut : 
Tabel 12.

Pengaruh Langsung

\begin{tabular}{lccc}
\hline & $\begin{array}{c}\text { Original } \\
\text { Sample }(\mathbf{O})\end{array}$ & $\begin{array}{c}\text { T Statistics } \\
(\text { (OO/STDEVl) }\end{array}$ & P Values \\
\hline Brand Image _.Niat Beli Ulang & 0,353 & 3,423 & 0,001 \\
Kualitas Produk _. Brand Image & 0,889 & 35,861 & 0,000 \\
Kualitas Produk _.Niat Beli Ulang & 0,556 & 5,752 & 0,000 \\
\hline
\end{tabular}

Sumber: Data diolah 2018.

Berdasarkan hasil analisis PLS pada tabel 12 menunjukkan arah masingmasing variabel bebas terhadap variabel terikatnya. Hasil tersebut dapat diuraikan sebagai berikut:Pengaruh kualitas barang atau jasapada niat beli ulang sebesar $+0,556$, memberikan petunjuk bahwasannya kualitas barang atau jasa memiliki pengaruh positif pada niat beli ulang produk smartphone samsung di kota Denpasar, apabila kualitas produk meningkat maka niat beli ulang akan meningkat sebesar 0,556. Berdasar kepadaTabel 12 dapat kita ketahui bahwasannya nilai signifikans $p$-value sejumlah $0,000 \leq 0,05$, jadi $\mathrm{H}_{0}$ ditolak. Hasil tersebutmemiliki arti memiliki pengaruh positif serta signifikan pada niat beli ulangproduk smartphone samsung di kota Denpasar.

Pengaruh kualitas produk terhadap brand image ulang sebesar $+0,889$, menunjukkan bahwa kualitas produk berpengaruh positif terhadap brand image produk smartphone samsung di kota Denpasar, apabila kualitas produk meningkat maka niat beli akan meningkat sebesar 0,889. Berdasar kepadaTabel 12 dapat kita ketahui bahwasannya nilai signifikansi p-value sejumlah $0,000 \leq 0,05$, jadi $\mathrm{H}_{0}$ ditolak. Hasil itu memiliki arti memiiki pengaruh positif serta signifikan pada brand image produk smartphone samsung di kota Denpasar. 
Pengaruh brand image pada niat beli ulang sejumlah $+0,353$, memberikan petunjuk bahwasannyabrand image memiliki pengaruh positif pada niat beli ulang produk smartphone samsung di kota Denpasar, apabila brand image produk smartphone samsung di masyarakat meningkat maka niat beli ulang akan mengalami peningkatan sebesar 0,353.Berdasar kepadaTabel 12 ddapat kita ketahuibahwasannya nilai signifikansi $p$-value sejumlah $0,001 \leq 0,05$, sehingga $\mathrm{H}_{0}$ ditolak. Hasil tersebut memiliki artimemiliki pengaruh positif serta signifikan pada niat beli ulangproduk smartphone samsung di kota Denpasar.

Tabel 13.

Indirect Effect

\begin{tabular}{lccc}
\hline & $\begin{array}{c}\text { Original } \\
\text { Sample }(\mathbf{O})\end{array}$ & $\begin{array}{c}\text { T Statistics } \\
(\text { (O/STDEVl) }\end{array}$ & P Values \\
\hline Kualitas Produk, Niat Beli Ulang & 0,314 & 3,361 & 0,001 \\
\hline Sumber: Data diolah 2018. & & &
\end{tabular}

Sumber: Data diolah 2018.

Pengaruh tidak langsung kualitas produk terhadap niat beli ulang melalui brand image sebesar $+0,314$, menunjukkan bahwa kualitas produk melalui brand image berpengaruh positif terhadap niat beli ulang produk smartphone samsung di kota Denpasar.Berdasarkan tabel 13 diketahui bahwa nilai signifikansi p-value sebesar $0,001 \leq 0,05$, maka $\mathrm{H}_{0}$ ditolak. Ini berarti berpengaruh positif dan signifikan terhadap niat beli ulang produk smartphone samsung di kota Denpasar dengan dimediasi oleh brand image.

Hasil ujivariabel mediasi menggunakan metode VAF sudahlolos beberapa pernyataan dimana, pertama pengaruh langsung (a) variable kualitas produk (X1) terhadap niat beli ulang (Y) tidak memperlibatkan variable mediasi brand image (X2) di model, sudah didapatkan hasil signifikan. Kedua, sesudah variablebrand 
image (X2) masuk kedalam model, jadi pengaruh tidak langsung ( $\mathrm{b} \quad \mathrm{x}$ c) didapatkan hasil signiifikan. Jalur b serta c signifikan pula. Ketiga, melakukan perhitunganVariance Accounted For (VAF) menggunakan rumus :

$$
\begin{aligned}
\mathrm{VAF} & =(\mathrm{a} \times \mathrm{b}) /(\mathrm{a} \times \mathrm{b}+\mathrm{c}) \ldots \ldots \ldots \ldots \ldots \ldots \ldots \ldots \ldots \ldots \ldots \ldots \ldots \ldots \ldots \ldots \ldots \ldots \ldots \ldots \ldots \ldots \\
& =(0,889 \times 0,353) /(0,889 \times 0,353+0,869) \\
& =(0,314) /(1,182) \\
& =0,265 \text { atau } 26,5 \%
\end{aligned}
$$

Karena nilai VAF $(26,5 \%)$ berada direntang $20 \%$ hingga $80 \%$ jadibisa dimasukkan kedalam kategori pemediasi parsial (partial mediation).

\section{SIMPULAN DAN SARAN}

Berdasarkan hasil pembahasan penelitian yang telah dilakukan, maka dapat disimpulkan bahwa: 1) Kualitas produk berpengaruh positif dan signifikan terhadap brand image. Hal ini menunjukan bahwa semakin tinggi kualitas produk smartphone Samsung maka semakin baik brand image dari produk smartphone Samsung di Kota Denpasar. 2) Kualitas produk berpengaruh positif dan signifikan terhada niat beli ulang. Hal ini menunjukan bahwa semakin tinggi kualitas produk smartphone Samsung maka semakin tinggi pula niat konsumen untuk membeli kembali produk smartphone Samsung di Kota Denpasar. 3) Brand image berpengaruh positif dan signifikan terhadap niat beli ulang.Hal ini menunjukan bahwa semakin baik brand imagesmartphone Samsung maka semakin tinggi pula niat konsumen untuk membeli kembali produk smartphone Samsung di Kota Denpasar. 4) Brand image mampu memediasi pengaruh kualitas produk terhadap niat beli ulang smartphone Samsung di Kota Denpasar. 
Saran yang dapat diberikan berdasarkan pada hasil analisis, pembahasan dan simpulan dari penelitian ini adalah sebagai berikut: 1) Perusahaan harus memperhatikan kualitas produk dan brand image, kualitas produk yang baik akan membuat citra positif dibenak konsumen. Berdasarkan nilai deskriptif terkecil variabel kualitas produk terdapat pada pertanyaan "menurut saya secara keseluruhan produk smartphone Samsung memiliki kualitas yang baik" ini berarti pihak Samsung harus lebih memperhatikan kualitas produknya secara keseluruhan. Sedangkan pada variabel brand image nilai deskriptif terkecil terdapat pada pertanyaan "meurut saya produk smartphone Samsung memiliki teknologi canggih" hal ini harus diperhatikan oleh Samsung untuk mengembangkan teknologinya dengan menambahkan fitur-fitur yang lebih canggih yang sesuai dengan kebutuhan konsumen, sehingga niat beli ulang konsumen akan menjadi lebih tinggi. Hal ini penting untuk dilakukan dalam membangun perusahaan yang mampu bersaing dengan perusahaan lain atau pesaing. 2) Bagi peneliti selanjutnya diharapkan mampu menambahkan variabelvariabel yang dapat mempengaruhi niat beli ulang, dan mampu untuk memperluas ruang lingkup penelitian yang tidak hanya terbatas pada satu lokasi penelitian atau suatu produk tertentu sehingga dapat memberikan suatu pandangan yang lebih dan mampu diimplementasikan secara umum.

\section{REFERENSI}

Andreani. (2012). The Impact of Brand Image Towards Loyalty with Satisfacation as A Mediator in McDonald's. Jurnal Manajemen dan Kewirausahaan. 14(1):64-71. 
Andriadi, Akmal., dan Untarini, Nindria. (2013). Pengaruh Persepsi Kualitas Layanan dan Citra Merek Telkom Flexi Terhadap Niat Beli Ulang. Journal Ilmu Manajemen. 1(2): 639-649.

Anis L.M., Suharyono, Sunarti, (2015), "Pengaruh Kualitas Produk Terhadap Internasional Brand Image Serta Dampaknya Terhadap Keputusan Pembelian Mahasiswa Pembeli Dan Pengguna Laptop Lenovo Di Fakultas Ilmu Administrasi Universitas Brawijaya", Jurnal Administrasi Bisnis, Unoiersitas Brawijaya Malang. 28(2): 1-6.

Anggitan, Rizana, A. R. (2013). Analisis Pengaruh Kualitas Produk, Harga dan Promosi Terhadap Loyalitas Pelanggan Dengan Minat Beli Ulang Sebagai Variabel Intervening (Studu Pada Shibuya Resto Citraland Mall Semarang). Jurnal Managemen.2(7): 1-18.

Annafik, A. F. dan M. rahardjo. (2012). Analisis Pengaruh Kualitas Produk, Harga, Dan Daya Tarik Iklan Terhadap Niat Membeli Sepeda Motor Yamaha (Studi Kasus Pada Konsumen Yamaha Ss Cabang Kadungmudu Semarang). Journal Of Management. 1(2):247-281.

Amryyanti, Ruth. (2013). Pengaruh Kualitas Layanan, Produk, dan Kewajaran Harga Terhadap Kepuasan dan Loyalitas Pelanggan Pada Lnc Skin Care Singaraja. E-Jurnal Ekonomi dan Bisnis Universitas Udayana, 2(1): 22-29.

Arfiani Bahar, dan Herman Sjaharuddin. (2015). Pengaruh Kualitas Produk Dan Kualitas Pelayanan Terhadap Kepuasan Konsumen Dan Minat Beli Ulang. Jurnal Organisasi dan Manajemen: Sekolah Tinggi Ilmu Ekonomi Bongaya Makasar, 3(1): 1-34

Astiani Yunus., (2014). Pengaruh Kualitas Produk, Lokasi dan Lingkungan Fisik Terhadap Pembelian Ulang Pada Warung Kopi Harapan J2 di Kota Palu. EJurnal Katalogis. Universitas Tadulako. 2(7): 1-12

Chaudhuri, Arjun and Mark Ligas (2009), "Consequences of Value in Retail Market”, Journal of retailing, 85 (3): 406-419

Ghozali, Imam, (2011). Aplikasi Analisis Multivariate Dengan Program SPSS, Edisi Keempat. Penerbit Universitas Diponogoro.

Jakpar, Shaharudin, Na, A.G.S., dan Johari, Anita. (2012). Examining The Product Quality Attributes That Influences Customer Satisfacation Most When The Price Was Discounted: A Case Study in Kuching Sarawak. International Journal Of Business and Social Science. 3(23): 221-236.

Kiswalini A (2014). Pengaruh Celebrity Endorser, Brand Image dan Kepercayaan Konsumen Terhadap Keputusan Pembeliaan. E-Jurnal Manajemen Universitas Udayana, 3(6): 1522-1534. 
Kotler, P. (2012). Manajemen Pemasaran Perspektif Asia (pertama). Yogyakarta: Andi.

Kotler, P., \& Keller, K.L. (2012). Marketing Management (14th ed). New Jersey: Pearson Prestice Hall.

Kotler dan Amstrong, (2014). Prinsip-Prinsip Marketing, Jakarta: Salemba Empat.

Lupiyoadi, Rambat. (2001). Manajemen Pemasaran Jasa. Edisi Pertama. Jakarta: Salemba Empat.

Madahi, Abdolrazagh., dan Sukati, Inda., (2012), "The Effect of External Factors on Purchase Intenion amongst Young Generation in Malaysia", International Business Research, 5(8): 153-159.

Musaddat. M., A. (2011). Pengaruh minat beli ulang terhadap loyalitas konsumen Cimory Youghurt Drink (Studi kasus CMP Botani Square Bogor). 7(2): 122134.

Pebriana Aryadhe, dan Ni Made Rastini. (2016). Kualitas Pelayanan, Kualitas Produk dan Citra Merek terhadap Niat Beli Ulang di PT. Agung Toyota Denpasar. E-jurnal Manajemen Unud. 5(9): 5696-5721.

Rangkuti, Freddy. (2002). Measuring Customer Satisfaction Teknik Mengukur dan Strategi Meningkatkan Kepuasan Pelanggan dan Analisis Kasus PLNJP. PT. Gramedia Pustaka Utama, Jakarta.

Rizan, Mohammad, Basrah Saidani, Samsul Arifin dan Yusiyana Sari. 2012. Pengaruh Brand Image dan Brand Trust Terhadap Brand Loyality Teh Botol Sosro Survey Konsumen The Botol Sosro di Food Court Itc Cempaka Mas, Jakarta Timur. Jurnal Riset Managemen sains Indonesia (JRMSI). 3 (1): 117.

Roslina. (2010). Citra Merek : Dimensi, Proses Pengembangan Serta Pengukurannya. Jurnal Bisnis dan Managemen. 6(3): 333-346.

Saraswati, Renilda. (2014). Pengaruh Brand Image Terhadap Pengambilan Keputusan Pembelian Ulang Produk Herbalife (Studi Kasus pada Lima Rumah Sakit Sehat Bekasi Utara). Jurnal Managemen. Institut Pertanian Bogor. 2(7): 153-165.

Suciningtyas, Wulan. (2012). Pengaruh Brand Awareness, Brand Image, dan Media Communication Terhadap Keputusan Pembelian. Management Analysis Journal. 1(1): 1-8.

Sugiyono. (2017). Metode Penelitian Bisnis. Bandung: CV Alfabeta. 
E-Jurnal Manajemen, Vol. 8, No. 4, 2019: 2555 - 2583

Tariq, M. Irfan., dkk. (2013). Customer Perceptions about Branding and Purchase Intention: A Study of FMCG in an Emerging Market. Journal of Basic and Applied Scientific Research, 3(2): 340-347.

Thakur, Satendra and Dr. A. P Singh. (2012). Brand Image, Customer Satisfaction and Loyalty Intention: A Study in The Context of Cosmetic Product Among The People of Central India. International Journal of Multidisciplinary Management Studies, 2(5): 22498834.

Tjahjaningsih., Endang \& Maurine Yuliani. (2009). Analisis Kualitas Produk dan Citra Merek dalam Mempengaruhi Keputusan Pembelian dan Dampaknya Terhadap Loyalitas Merek HP NOKIA.TEMA, 6(2): 104-118.

Wijaya, Himan. (2014). Consumer's Perception, Attitude and Repurchase. 